Published in final edited form as: Pediatr Blood Cancer. 2016 Feb;63(2):318-25. doi: 10.1002/pbc.25755

\title{
Follow-Up Care of Adolescent Survivors of Childhood Cancer: The Role of Health Beliefs
}

Judith E. Lupatsch, MSc ${ }^{1}$; Laura Wengenroth, $\mathrm{PhD}^{1}$; Corina S. Rueegg, $\mathrm{PhD}^{1,4}$; Oliver Teuffel, MD, MSc ${ }^{2}$; Fabienne Gumy-Pause, $\mathrm{MD}^{3}$; Claudia E. Kuehni, MD, $\mathrm{MSc}^{1}$; and Gisela Michel, PhD; ${ }^{1,4}$ for the Swiss Paediatric Oncology Group (SPOG)*

${ }^{1}$ Swiss Childhood Cancer Registry, Institute of Social and Preventive Medicine, University of Bern; Bern, Switzerland

${ }^{2}$ Departement of Pediatric Hematology-Oncology, Bern University Hospital; Bern, Switzerland

${ }^{3}$ Department of Pediatrics, University Hospital of Geneva; Geneva, Switzerland

${ }^{4}$ Department of Health Sciences and Health Policy, University of Lucerne; Lucerne, Switzerland

* Swiss Paediatric Oncology Group: R. Ammann, Bern; R. Angst, Aarau; M. Ansari, Geneva; M. Beck Popovic, Lausanne; E. Bergstraesser, Zurich; P. Brazzola, BellinzonaJ. Greiner, St. Gallen; M. Grotzer, Zurich; H.

Hengartner, St. Gallen; T. Kühne, Basel; K. Leibundgut, Bern; F. Niggli, Zurich; J. Rischewski, Lucerne; N.X. von der Weid, Basel.

\section{CORRESPONDING AUTHOR}

Gisela Michel, PhD

Department of Health Sciences and Health Policy

University of Lucerne

Frohburgstrasse 3, PO Box 4466

6002 Lucerne, Switzerland

Phone: +41 22959 55; fax: +41 2295635

Email: gisela.michel@unilu.ch

\section{Citation:}

Lupatsch, Judith E.; Wengenroth, Laura; Rueegg, Corina S.; Teuffel, Oliver; Gumy-Pause, Fabienne; Kuehni, Claudia E.; Michel, Gisela (2016). Follow-up care of adolescent survivors of childhood cancer: The role of health beliefs. Pediatric blood \& cancer, $63(2)$, S. 318-25. Wiley $10.1002 /$ pbc. 25755

\footnotetext{
ABASTRACT

Background: Little is known about follow-up care attendance of adolescent survivors of childhood cancer, and which factors foster or hinder attendance. Attending follow-up care is especially important for adolescent survivors to allow for a successful transition into adult care. We aimed to (1) describe the proportion of adolescent survivors attending follow-up care, (2) describe adolescents' health beliefs, and (3) identify the association of health beliefs,demographic and medical factors with follow-up care attendance.

Procedure: Of 696 contacted adolescent survivors diagnosed with cancer at $\leq 16$ years of age, $\geq 5$ years after diagnosis, and aged 16-21 years at study, 465 (66.8\%) completed the Swiss Childhood Cancer Survivor Study questionnaire. We assessed follow-up care attendance and health beliefs, and extracted demographic and medical information from the Swiss Childhood Cancer Registry. Cross-sectional data were analyzed using descriptive statistics and logistic regression models.

Results: Overall, 56\% survivors reported attending follow-up care. Most survivors (80\%) rated their susceptibility for late effects as low and believed that follow-up care may detect and prevent late effects (92\%). Few (13\%) believed that follow-up care is not necessary. Two health beliefs were associated with follow-up care attendance (perceived benefits: odds ratio [OR]:1.56; 95\% confidence interval [CI]:1.07-2.27; perceived barriers: OR:0.70; 95\% CI: 0.50-1.00). Conclusions: We show that health beliefs are associated with actual follow-up care attendance of adolescent survivors of childhood cancer. A successful model of health promotion in adolescent survivors should therefore highlight the benefits and address the barriers to keep adolescent survivors in follow-up care.

KEYWORDS

Adolescent survivors, follow-up care, health beliefs, Swiss Childhood Cancer Survivor Study
} 
Published in final edited form as: Pediatr Blood Cancer. 2016 Feb;63(2):318-25. doi: 10.1002/pbc.25755

\section{INTRODUCTION}

With increasing survival rates [1], the long-term effects of childhood cancer and its treatment become apparent. These include second malignancies, cardiovascular or endocrine problems, and psychological distress [2-4]. In order to improve quality of survival and prevent long-term effects, regular follow-up visits are recommended for most survivors $[5,6]$.

While follow-up care attendance has been studied in adult survivors of childhood cancer [7,8], little is known about the follow-up care attendance of adolescent survivors and which factors foster or hinder attendance. Attending follow-up care might be especially important during adolescence to allow for a successful transition into adult care [9]. If survivors lose contact with their follow-up team already in adolesence, they may fail to transition to adult care and be lost to follow-up care later in life.

Our objective in the present study was to describe follow-up care attendance of adolescent survivors of childhood cancer in Switzerland within the framework of the Health Belief Model. The Health Belief Model (HBM) [10-13] is a social cognitive model that has been widely used to explain preventive health behavior, such as breast-cancer screening, use of sun screen, or use of condoms [14-16]. It has also successfully been used to predict adolescents' preventive healthrelated behavior such as diabetes management, keeping appointments, or use of condoms [1720].

The HBM was developed in the early 1950s to predict individual health-prevention behavior. It contains four main factors: (1) perceived susceptibility, the subjective feeling of risk or vulnerability to a disease or condition; (2) perceived severity, the perceived seriousness of contracting an illness; (3) perceived benefits, the subjective assessments of the possible advantages of potential health behaviors; and (4) perceived barriers, the subjective feelings that a health behavior might also have negative aspects, such as being unpleasant or upsetting. A further factor has been added to the model called cues to action $[16,21]$. It can be thought of as a trigger for the actual behavior.

We have used this model previously to explore why only a relatively small proportion of adult-aged survivors of childhood cancer attend regular follow-up care [22]. We found that only $23 \%$ of survivors attended follow-up care and that perceived barriers were significantly associated with lack of attendance.

In the present analysis we aimed to (1) assess the proportion of adolescent survivors of childhood cancer attending follow-up care; (2) describe adolescents' health beliefs; and (3) identify the association of health beliefs, demographic and medical factors with follow-up care attendance.

\section{METHODS}

\section{Sample and procedure}

The Swiss Childhood Cancer Survivor Study (SCCSS) is a nationwide long-term followup study of all patients registered in the Swiss Childhood Cancer Registry (SCCR) between 1976 and 2005, who were Swiss residents at time of diagnosis and survived cancer for 5 years or more [23]. The SCCR is a population-based registry including all children and adolescents diagnosed with leukemia, lymphoma, central nervous system (CNS) tumor, malignant solid tumor, or Langerhans cell histiocytosis before the age of 16 years $[24,25]$. The SCCSS contains three different subgroups who all received separate, age-adapted questionnaires : Children $<16$ years of age, adolescents aged 16-19 years, and adults aged 20+ years, at the time the questionnaire was sent. For the current analyses we included only survivors who returned the SCCSS questionnaire for adolescents.

All survivors eligible for the SCCSS received an information letter about the study from the hospital where they had been treated. Letters were written in the corresponding language that was registered for the respective patient at the hospital (German, French, or Italian). A comprehensive address search guaranteed that almost all eligible survivors were contacted. They were asked to reply if they did not wish to participate, if their address had changed or if they required the questionnaire in a different language other than the one we used in the information letter (SupplementalText1). Two weeks later all survivors who had not refused to participate were sent a questionnaire with a prepaid return envelope (Supplemental Text2). Nonresponders received another questionnaire after two months and were then contacted by phone 
Published in final edited form as: Pediatr Blood Cancer. 2016 Feb;63(2):318-25. doi: 10.1002/pbc.25755

and invited to participate.

Ethics approval for this study was provided through the general cancer registry permission of the SCCR (Swiss Federal Expert Commission for Professional Secrecy in Medical Research) and a non-obstat statement (the ethical committee did not object the running of the study) was obtained from the cantonal (regional) ethics committee of Bern, Switzerland.

\section{Measures}

The SCCSS used an extensive crosssectional questionnaire, similar to major childhood cancer survivor studies in the United States and the United Kingdom [26,27], assessing quality of life, health beliefs, somatic health, fertility, current medication and health service utilization, health behaviors, and sociodemographic information.

Follow-up care

In the SCCSS questionaire for adolescents, survivors were asked if they were still in regular follow-up care for their previous cancer ( $1=$ Yes, I still attend regular follow-up appointments in the clinic where I was treated, 2 $=$ Yes, I still have regular follow-up appointments, but with a medical doctor outside the hospital or at another hospital than the one I was treated, $3=$ No, regular follow-up is completed, but I sometimes visit a doctor for a check-up, or $4=$ No, regular follow-up is completed and I have not seen a doctor for a while). For analyses responses (1) and (2) were pooled and labeled as attending follow-up, and responses (3) and (4) were pooled and labeled as not attending follow-up.

Health beliefs.The questionnaires covered the four main HBM dimensions and cues to actions. All questions were specifically developed as part of the SCCSS. Development included piloting the questions with 50 survivors. Questions were introduced by inviting survivors to indicate which response best describes their own situation on the provided likert scales. To measure perceived susceptibility we asked suvivor to rate their perceived probability of experiencing late effects within the next 10 years. Perceived severity was assessed with the following item: If I suffer from late effects, this will considerably impair my daily life. Perceived benefits were captured by asking participants to mark the level of their agreement with the following item: Regular follow-up care may help in detecting late effects and preventing negative consequences of late effects of my cancer. Perceived barriers were assessed by asking participants to mark the level of their agreement with the following statements: (1) Regular follow-up care is not necessary, and (2) At regular follow-up care appointments, I fear that negative late effects of my cancer will be found. For cues to action we asked (1) if participants already suffered from late effects. If yes, survivors were asked how severely these late effects impair their day-to-day life, and (2) about their general health status.

Sociodemographic characteristics. Survivors were asked about their age, gender, their educational background (still at school, vocational training, work), and the educational achievement of their parents (university education yes or no) and if they were born in Switzerland or abroad [28]. Information was also available on the language region (German, French, Italian).

Medical characteristics. Basic medical information on diagnoses and treatment of each survivor was extracted from the SCCR. Diagnoses were classified according to the International Classification of Childhood Cancer - Third edition [29]. For the regression models, diagnoses were pooled into five major groups: leukemia, lymphoma, CNS tumors, bone tumors, and other solid tumors. Time since diagnosis was coded into three categories (5-9 years, 10-14 years, $15+$ years); treatment was coded into surgery only, chemotherapy (without radiotherapy, may have had surgery), and radiotherapy (may have had surgery or chemotherapy). We also included information on bone marrow transplantation (BMT) and noted if the survivor had had a relapse.

\section{Analyses}

All statistical analyses were conducted with STATA 12.1 (College Station, TX). Hypotheses testing were done at the 5\% confidence level, using chi-square and likelihood-ratio tests (two-sided tests). First, descriptive statistics for follow-up care attendance and health beliefs, as well as differences in health beliefs between follow-up care attendees vs. non-attendees were calculated using chi-square tests. Second, we estimated univariable logistic regressions of follow-up care 
Published in final edited form as: Pediatr Blood Cancer. 2016 Feb;63(2):318-25. doi: 10.1002/pbc.25755

attendance on all health-belief, demographic and medical factors. Third, we estimated two nested multivariable logistic models to account for the adjusted effects. One of these models contained only demographic and medical factors, while the other one also included the health-belief factors in order to show if health beliefs have an independent effect in addition to demographic and medical factors.

\section{RESULTS}

A total of 781 adolescent survivors were eligible (Figure 1). Of these, 696 were contacted through valid addresses. We received completed questionnaires from 465 (66.8\%) survivors (257 males, 55.3\%). The mean age at study (time the questionnaire was returned to the study centre) was 17.9 years (range: 16-21), the median age at diagnosis was five years, and the median time since diagnoses was 13 years. The responders had been diagnosed with cancer at a younger age than non-responders. There were no other significant differences between study participants and nonparticipants (Table I).

\section{Follow-up care}

Among the 465 study participants, 410 responded to the question on follow-up care (Figure1). Of these, 195 reported that they attend follow-up care at a clinic (47.6\%; 95\% confidence interval [CI]: 42.7-52.4); 34 attend follow-up care with a doctor outside the hospital (8.3\%; 95\%CI: 5.6-11.0); 86 were no longer in follow-up care but still visit a doctor sometimes (21\%; 95\%CI: 17.0-25.0); and 95 reported not having seen a doctor for a while (23.2\%; 95\%CI: 19.0-27.0). For the analyses we combined answers 1 and 2 as well as 3 and 4: overall, 229 (55.9\%; 95\%CI: 51.0-61.0) were labled as follow-up care attendees and 181 (44.1\%; 95\%CI: 39.3-49.0) as not attending follow-up care.

There was no difference in follow-up care attendance by gender (male: 128/227, 55.4\%; female: $101 / 183$, 55.2\%; $\mathrm{p}=0.81$ ), or between those born in Switzerland (203/369; $55.1 \%)$ or abroad (26/41; 63.4\%; $\mathrm{p}=0.30)$. There were no differences in follow-up care attendance according to educational background. Of those in vocational training, 53.1\% (93/175) reported attending follow-up care; of those still at school, $58.4 \%$ (104/178); and of those who were already in the labor market, $60.0 \%(14 / 23)$ reported attending follow-up care. Parents' educational background was also similar: 58.8\% (60/102) of those who had at least one parent with university degree attended follow-up care vs. 54.9\% $(169 / 308 ; p=0.49)$ of those who had no parent with university degree.

\section{Health beliefs}

Most survivors (334; 80.3\%; 95\%CI: 76.5-84.2) rated their susceptibility (i.e., the probability of developing late effects in the next 10 years) as low (between 0 and 33\%). Regarding severity, 224 survivors (54.5\%; 95\%CI: 49.759.3) believed that late effects would impair their lives only slightly or not at all. Most survivors agreed moderately or strongly (394; 91.6\%; 95\%CI: 89.0-94.3) that follow-up care might detect and prevent late effects (benefits). Only 55 (12.8\%; 95\%CI: 9.6-15.9) were strongly or mostly convinced that follow-up care was unnecessary (barriers) (Table II).

Predictors of follow-up care attendance

Univariable analyses revealed significant associations between follow-up care attendance and two of the HBM items (Table III): perceived benefits (OR=1.59; 95\%CI: 1.18-2.16) and barriers, item 1 (OR=0.67; 95\%CI: 0.51-0.89). The other items were not significantly associated. When survivors perceived benefits they were more likely to attend follow-up care, and when they perceived barriers they were less likely to attend. Adolescents closer to time of diagnosis ( $p$ $<0.001$ ) and those who had bone marrow transplants were also more likely to attend follow-up care $(p<0.001)$.

Also both multivariable models (Table III) showed that the odds of attending follow-up care decreased with the amount of time since diagnosis ( $p<0.001)$ and that type of therapy was associated with follow-up visits ( $p<0.001$ ). Treatment with bone marrow transplant was also strongly associated with follow-up care attendance in both models (model 1: OR=15.21, 95\%CI: 1.87-123-53; model 2: OR=19.15, 95\%CI: 2.25-163.07). In model 2, which also included the health belief factors in addition to the demographic and medical factors, survivors were more likely to attend follow-up care when they believed follow-up care was suitable to detect and prevent late effects (perceived benefits: $\mathrm{OR}=1.56$; 95\%CI: 1.07-2.27). In contrast, survivors who believed that follow-up care is 
Published in final edited form as: Pediatr Blood Cancer. 2016 Feb;63(2):318-25. doi: 10.1002/pbc.25755

unnecessary were less likely to attend follow-up care (perceived barriers: OR=0.70; 95\%CI: 0.50 1.00). This extended model 2 had a better fit according to likelihood ratio testing $\left(\chi^{2}(14)=\right.$ 67.8; $\mathrm{p}<0.001)$. We did not include relapse in the models because it correlated perfectly with follow-up care attendance-all survivors who experienced a relapse reported that they still attended follow-up care.

\section{DISCUSSION}

We found that only about half of adolescent survivors of childhood cancer still attended follow-up care. Health beliefs were associated with follow-up care attendance in addition to demographic and medical factors. Perceived benefits (the belief that follow-up care may help to detect and prevent late effects) increased the likelihood of attendance, while perceived barriers (the belief that follow-up care is not necessary) decreased the likelihood. In addition, adolescent survivors who were more recently diagnosed or had a bone marrow transplantation were more likely to attend followup care. All survivors who had a relapse also attended follow-up care.

This study described follow-up care attendance in adolescent childhood cancer survivors and analyzed the role of demographic and medical factors as well as health beliefs. One previous study showed that adolescent cancer survivors had less positive health beliefs compared to healthy peers [30]. Another study investigated the association between health beliefs and interest in cancer screening among adolescent survivors. In that study, survivors who rated themselves to be more concerned about cancer, more vulnerable to cancer (higher susceptibility) and more competent (higher selfefficacy, a factor not used in the original HBM) were more interested in participating in cancer screening [31]. An intervention study among adolescent childhood cancer survivors showed that perceived personal risk for late effects and motivation to change health behaviour was modifiable and improved with both standard care and multi-component test intervention [32,33].

When comparing the rate of follow-up care attendance between the adolescent survivors in this study with that in our previous study with adults [22], we found that more adolescents reported attending follow-up care compared to the adults (56\% vs. $23 \%$ ). This may be due to adolescent participants being, on average, more recently diagnosed (median: 13 years) than were the adult participants (median: 20 years). Similar to adolescents, for health beliefs, we also found a significant association between perceived barriers and follow-up visits in adult participants; but unlike in adolescent survivors, there was no association for perceived benefits. Yet, for the adolescents, the perception of benefits from attending follow-up also seemed to be important, meaning that they need to perceive a positive effect in order to pursue a behavior. While most adolescent survivor did not report any late effects almost half of adult survivors did. The reality that most late effects cannot be prevented but only detected early might have reduced their belief in this kind of benefit of follow-up care. The associations between medical factors and followup care attendance are in line with previous research on adult survivors of childhood cancer $[7,34]$.

This study's main strength is that, for the first time, the follow-up care attendance of adolescent survivors was investigated and analyzed with respect to psychological, sociodemographic, and medical characteristics. Additionally, we drew upon a population-based cohort with a high response rate, increasing the reliability of our results.

However, there are some limitations that should be considered. As with all self-report questionnaires, participants may not accurately remember and report their behavior. Selfselection is an other potential limitation: it is possible that follow-up care attenders were overrepresented in our sample, as they may be more likely to be interested in the study and return the questionnaire. Similarly, participants were on average slightly younger than non-participants and might thus be more likely to still attend follow-up possible because parents are more involved in their decisions that for older adolescents. Given that we used only crosssectional data, causation is unclear: health beliefs might have been influenced by earlier follow-up visits.The SCCSS included only few questions about health beliefs and other important dimensions could not be assessed; e.g. barriers such as knowledge of the hospital system; or cues 
Published in final edited form as: Pediatr Blood Cancer. 2016 Feb;63(2):318-25. doi: 10.1002/pbc.25755

to action such as parental support or advertisements. Also, self-efficacy - the perception that one is competent or capable of performing an action to meet a specific goal $[35,36]$ - was not assessed. Yet perceptions of self-efficacy influence the way people approach goals and their persistence when facing challenges in health behavior $[37,38]$. It may be important to take this dimension into account when designing future research projects in order to make more precise predictions about follow-up care attendance. Additionally, future research should take into account the health beliefs of parents who might still have an influence on their adolescent children and may directly influence the follow-up care attendance of their adolescents.

In Switzerland, follow-up care is well organized in pediatric oncology in the first 5 to 10 years after diagnosis. Thereafter, survivors are much more in charge to continue their follow-up care. Pediatric oncologists follow survivors long into adulthood if necessary. In order to improve follow-up care attendance, adolescent survivors' beliefs might be a key factor - beliefs about the necessity of follow-up care contribute to predicting actual attendance to follow-up care. Several models to improve health promotion in adolescent survivors have been proposed [39-41]. A successful model of health promotion in adolescent survivors should therefore highlight especially the benefits for adolescent survivors in receiving follow-up care, that will also lead to a successful transition. The information and education about regular follow-up care for young survivors and their parents should thus start with completion of treatment and educate the survivors about the cancer, treatment, potential late effects and the importance of follow-up care in a age-adapted way [42]. Later on, a wellorganised transition to adult care should follow, ideally led by an appointed transition coordinator. Benefits of follow-up care should be highlighted and possible barriers identified in order to address them early and professionally. A survivor passport with individually tailored follow-up care information is currently developed as a collaborative project between ENCCA (European Network for Cancer Research in Children and Adolescents) and PanCareSurFup (PanCare Childhood and Adolescent Cancer Survivor Care and Follow-Up Studies) to help survivors to get adequate follow-up care. Positive experiences of early follow-up appointments might also influence later beliefs regarding both benefits and barriers.

In this analysis, we showed that adolescent survivors' health beliefs are associated with follow-up care attendance. We suggest that regular information on the importance, effectiveness, and necessity of long-term followup care should be given to patients and their parents starting at the conclusion of therapy.

\section{ACKNOWLEDGEMENTS}

We thank all of the survivors and their families for participating in our survey, as well as the Swiss Childhood Cancer Survivor Study study team (Julia Koch, Micòl Gianinazzi, and Fabienne Liechti), the Swiss Paediatric Oncology Group data managers (Verena Stahel, Nadine Beusch, Heike Markiewicz, Genevieve Perrenoud, Myriam Crouche, Franziska Hochreutener, Yvonne Bonetti, and Rosa-Emma Garcia), and the Swiss Childhood Cancer Registry team (Vera Mitter, Elisabeth Kiraly, Marlen Spring, and Priska Wölfli). We also thank Kali Tal for her editorial assistance.

This work was supported by the Swiss Cancer League (grants KLS-01605-10-2004, KLS-2215-02-2008, KLS-02783-02-2011, and KFS-02631-08-2010), Cancer League Bern, Swiss Bridge, Stiftung zur Krebsbekämpfung, and the Swiss National Science Foundation (Ambizione grants PZ00P3_121682/1 and PZ00P3-141722 to Gisela Michel). The work of the Swiss Childhood Cancer Registry is supported by the Swiss Paediatric Oncology Group, Kinderkrebshilfe Schweiz, Stiftung für krebskranke Kinder Regio Basiliensis, Schweizerische Konferenz der kantonalen Gesundheitsdirektorinnen und-direktoren (GDK), and numerous other sponsors.

\section{CONFLICT OF INTEREST STATEMENT}

No competing interests exist for any of the authors. 
Published in final edited form as: Pediatr Blood Cancer. 2016 Feb;63(2):318-25. doi: 10.1002/pbc.25755

\section{REFERENCES}

1. Gatta G, Zigon G, Capocaccia R, Coebergh JW, Desandes E, Kaatsch P, Pastore G, Peris-Bonet R, Stiller CA. Survival of European children and young adults with cancer diagnosed 1995-2002. Eur J Cancer 2009:45(6):992-1005.

2. Michel G, Rebholz CE, von der Weid NX, Bergstraesser E, Kuehni CE. Psychological distress in adult survivors of childhood cancer: the Swiss Childhood Cancer Survivor Study. J Clin Oncol 2010:28(10):1740-1748.

3. Oeffinger KC, Mertens AC, Sklar CA, Kawashima T, Hudson MM, Meadows AT, Friedman DL, Marina N, Hobbie W, Kadan-Lottick NS, Schwartz CL, Leisenring W, Robison LL. Chronic health conditions in adult survivors of childhood cancer. N Engl J Med 2006:355(15):1572-1582.

4. Geenen MM, Cardous-Ubbink MC, Kremer LC, van den Bos C, van der Pal HJ, Heinen RC, Jaspers MW, Koning CC, Oldenburger F, Langeveld NE, Hart AA, Bakker PJ, Caron HN, van Leeuwen FE. Medical assessment of adverse health outcomes in long-term survivors of childhood cancer. J Am Med Assoc 2007:297(24):2705-2715.

5. Skinner R, Wallace WH, Levitt G. Long-term follow-up of children treated for cancer: why is it necessary, by whom, where and how? Arch Dis Child 2007:92(3):257-260.

6. Wallace WHB, Blacklay A, Eiser C, Davies H, Hawkins M, Levitt GA, Jenney MEM, on behalf of the Late Effects Committee of the United Kingdom Children's Cancer Study Group (UKCCSG). Developing strategies for long term follow up of survivors of childhood cancer. BMJ 2001:323(7307):271-274.

7. Rebholz CE, von der Weid NX, Michel G, Niggli FK, Kuehni CE. Follow-up care amongst longterm childhood cancer survivors: a report from the Swiss Childhood Cancer Survivor Study. Eur J Cancer 2011:47(2):221-229.

8. Arvidson J, Soderhall S, Eksborg S, Bjork O, Kreuger A. Medical follow-up visits in adults 5-25 years after treatment for childhood acute leukaemia, lymphoma or Wilms' tumour. Acta Paediatr 2006:95(8):922-928.
9. Freyer DR, Brugieres L. Adolescent and young adult oncology: transition of care. Pediatr Blood Cancer 2008:50(5 Suppl):1116-1119.

10. Becker MH, Maiman LA, Kirscht JP, Don PH, Drachman RH. The Health Belief Model and prediction of dietary compliance: a field experiment. J Health Soc 1977:18(4):348-366.

11. Hochbaum GM. Public participation in medical screening programs: a socio-psychological study. Washington, DC: United States Department of Health, Education, and Welfare; 1958.

12. Rosenstock IM. Why people use health services. Milbank Q 1966:44(3):94-127.

13. Rosenstock IM. Historical origins of the Health Belief Model. Health Educ Monogr 1974:2(4):1-8.

14. Abraham C, Sheeran P. The Health Belief Model. In: Conner M, Norman P, editors. Predicting health behaviour. Berkshire, England: Open University Press; 2005. p 28-80.

15. Harrison JA, Mullen PD, Green LW. A metaanalysis of studies of the Health Belief Model with adults. Health Educ Res 1992:7(1):107-116.

16. Janz NK, Becker MH. The Health Belief Model: a decade later. Health Educ Behav 1984:11(1):1-47.

17. Bond GG, Aiken LS, Somerville SC. The Health Belief Model and adolescents with insulindependent diabetes mellitus. Health Psychol 1992:11(3):190-198.

18. Irwin CE, Millstein SG, Ellen JM. Appointmentkeeping behavior in adolescents: factors associated with follow-up appointment-keeping. Pediatrics 1993:92(1):20-23.

19. Laraque D, McLean DE, Brown-Peterside P, Ashton D, Diamond B. Predictors of reported condom use in central Harlem youth as conceptualized by the Health Belief Model. J Adolesc Health 1997:21(5):318-327.

20. Orr DP, Langefeld CD. Factors associated with condom use by sexually active male adolescents at risk for sexually transmitted disease. Pediatrics 1993:91(5):873-879. 
Published in final edited form as: Pediatr Blood Cancer. 2016 Feb;63(2):318-25. doi: 10.1002/pbc.25755

21. Rosenstock IM. Historical origins of the health belief model. Health Education \& Behavior 1974:2(4):328-335.

22. Michel G, Kuehni CE, Rebholz CE, Zimmermann K, Eiser C, Rueegg CS, von der Weid NX. Can health beliefs help in explaining attendance to follow-up care? The Swiss Childhood Cancer Survivor Study. Psycho-Oncol 2010:20(10):10341043.

23. Kuehni CE, Rueegg CS, Michel G, Rebholz CE, Strippoli MP, Niggli F, von der Weid NX. Cohort profile: the Swiss Childhood Cancer Survivor Study. Int J Epidemiol 2012:41(6):1553-1564.

24. Michel G, von der Weid NX, Zwahlen M, Adam M, Rebholz CE, Kuehni CE. The Swiss Childhood Cancer Registry: rationale, organisation and results for the years 2001-2005. Swiss Med Wkly 2007:137(35-36):502-509.

25. Michel G, von der Weid NX, Zwahlen M, Redmond S, Strippoli MP, Kuehni CE. Incidence of childhood cancer in Switzerland: the Swiss Childhood Cancer Registry. Pediatr Blood Cancer 2008:50(1):46-51.

26. Hawkins MM, Lancashire ER, Winter DL, Frobisher C, Reulen RC, Taylor AJ, Stevens MC, Jenney M. The British Childhood Cancer Survivor Study: objectives, methods, population structure, response rates and initial descriptive information. Pediatr Blood Cancer 2008:50(5):1018-1025.

27. Robison LL, Mertens AC, Boice JD, Breslow NE, Donaldson SS, Green DM, Li FP, Meadows AT, Mulvihill JJ, Neglia JP, Nesbit ME, Packer RJ, Potter JD, Sklar CA, Smith MA, Stovall M, Strong LC, Yasui Y, Zeltzer LK. Study design and cohort characteristics of the Childhood Cancer Survivor Study: a multi-institutional collaborative project. Med Pediatr Oncol 2002:38(4):229-239.

28. Kuehni CE, Strippoli M-PF, Rueegg CS, Rebholz CE, Bergstraesser E, Grotzer M, von der Weid NX, Michel G. Educational achievement in Swiss childhood cancer survivors compared with the general population. Cancer 2012:118(5):14391449.

29. Steliarova-Foucher E, Stiller C, Lacour B, Kaatsch P. International Classification of Childhood Cancer, third edition. Cancer 2005:103(7):14571467.
30. Kazak AE, DeRosa BW, Schwartz LA, Hobbie W, Carlson C, Ittenbach RF, Mao JJ, Ginsberg JP. Psychological Outcomes and Health Beliefs in Adolescent and Young Adult Survivors of Childhood Cancer and Controls. J Clin Oncol 2010:28(12):2002-2007.

31. Tercyak KP, Nicolas M, Councill T, Prahlad S, Taylor KL, Shad AT. Brief report: health beliefs among survivors of childhood cancer. J Pediatr Psychol 2004:29(5):397-402.

32. Hudson MM, Tyc VL, Srivastava DK, Gattuso J, Quargnenti A, Crom DB, Hinds P. Multicomponent behavioral intervention to promote health protective behaviors in childhood cancer survivors: The Protect Study. Medical and Pediatric Oncology 2002:39(1):2-11.

33. Cox CL, McLaughlin RA, Rai SN, Steen BD, Hudson MM. Adolescent survivors: a secondary analysis of a clinical trial targeting behavior change. Pediatr Blood Cancer 2005:45(2):144154.

34. Shaw AK, Pogany L, Speechley KN, Maunsell E, Barrera M, Mery LS. Use of health care services by survivors of childhood and adolescent cancer in Canada. Cancer 2006:106(8):1829-1837.

35. Bandura A. Self-efficacy: toward a unifying theory of behavioral change. Psychol Rev 1977:84(2):191-215.

36. Rosenstock IM, Strecher VJ, Becker MH. Social learning theory and the Health Belief Model. Health Educ Behav 1988:15(2):175-183.

37. Conner M, Norman P. Predicting health behavior. Berkshire, England: Open University Press; 2005.

38. Schwarzer R. Modeling health behavior change: how to predict and modify the adoption and maintenance of health behaviors. Appl Psychol 2008:57(1):1-29.

39. Hudson MM, Patte C. Education and health promotion in adolescent and young adult cancer survivors. Pediatr Blood Cancer 2008:50(5 Suppl):1105-1108.

40. Elliot DL, Lindemulder SJ, Goldberg L, Stadler DD, Smith J. Health promotion for adolescent childhood leukemia survivors: building on 
Published in final edited form as: Pediatr Blood Cancer. 2016 Feb;63(2):318-25. doi: 10.1002/pbc.25755

prevention science and ehealth. Pediatr Blood Cancer 2013:60(6):905-910.

41. Schwartz LA, Brumley LD, Tuchman LK, et al. STakeholder validation of a model of readiness for transition to adult care. JAMA Pediatrics 2013:167(10):939-946.
42. Reiss J, Gibson R. Health care transition: destinations unknown. Pediatrics 2002:110(6 Pt 2):1307-1314. 
Published in final edited form as: Pediatr Blood Cancer. 2016 Feb;63(2):318-25. doi: 10.1002/pbc.25755

TABLE I. Differences Between Study Participants and Non-Participants

\begin{tabular}{|c|c|c|c|c|c|}
\hline & \multicolumn{2}{|c|}{$\begin{array}{l}\text { Participants } \\
(n=410)\end{array}$} & \multicolumn{2}{|c|}{$\begin{array}{c}\text { Non- } \\
\text { participants } \\
(n=286) \\
\end{array}$} & \multirow[t]{2}{*}{$p\left(\chi^{2}\right)$} \\
\hline & $n$ & $\%$ & $n$ & $\%$ & \\
\hline \multicolumn{6}{|l|}{ Sex } \\
\hline Male & 227 & 55.4 & 172 & 60.1 & \\
\hline Female & 183 & 44.6 & 114 & 39.9 & 0.210 \\
\hline \multicolumn{6}{|l|}{ Age at study ${ }^{\mathrm{a}}$} \\
\hline 16 & 50 & 12.2 & 23 & 8.1 & \\
\hline 17 & 113 & 27.6 & 69 & 24.2 & \\
\hline 18 & 127 & 31.0 & 68 & 23.9 & \\
\hline 19 & 68 & 16.6 & 61 & 21.4 & \\
\hline 20 & 42 & 10.2 & 47 & 16.5 & \\
\hline 21 & 10 & 2.4 & 15 & 5.3 & \\
\hline 22 & 0 & 0.0 & 2 & 0.70 & $<0.001$ \\
\hline \multicolumn{6}{|l|}{ Language } \\
\hline German & 279 & 68.0 & 198 & 69.2 & \\
\hline French & 117 & 28.5 & 74 & 25.9 & \\
\hline Italian & 14 & 3.4 & 14 & 4.9 & 0.500 \\
\hline \multicolumn{6}{|l|}{ Age at diagnosis (years) } \\
\hline $0-4$ & 209 & 51.0 & 134 & 46.9 & \\
\hline 5-7 & 87 & 21.2 & 56 & 19.6 & \\
\hline $8-11$ & 88 & 21.5 & 66 & 23.1 & \\
\hline $12-14$ & 26 & 6.30 & 30 & 10.5 & 0.203 \\
\hline \multicolumn{6}{|l|}{ Time since diagnosis (years) } \\
\hline $5-9$ & 91 & 22.2 & 72 & 25.2 & \\
\hline $10-14$ & 135 & 32.9 & 97 & 33.9 & \\
\hline $15+$ & 184 & 44.9 & 117 & 40.9 & 0.522 \\
\hline \multicolumn{6}{|l|}{ Diagnosis } \\
\hline Leukemia & 135 & 32.9 & 92 & 32.2 & \\
\hline Lymphoma & 52 & 12.7 & 30 & 10.5 & \\
\hline Central nervous system tumor & 69 & 16.8 & 57 & 19.9 & \\
\hline Neuroblastoma & 24 & 5.9 & 19 & 6.6 & \\
\hline Retinoblastoma & 15 & 3.7 & 11 & 3.8 & \\
\hline Renal tumors & 41 & 10.0 & 15 & 5.2 & \\
\hline Hepatic tumors & 2 & 0.5 & 2 & 0.7 & \\
\hline Bone tumor & 13 & 3.2 & 12 & 4.2 & \\
\hline Soft tissue sarcoma & 20 & 4.9 & 15 & 5.2 & \\
\hline Germ cell tumor & 14 & 3.4 & 8 & 2.8 & \\
\hline Other tumor & 4 & 1.0 & 6 & 2.1 & \\
\hline Langerhans cell histiocytosis & 21 & 5.1 & 19 & 6.6 & 0.570 \\
\hline \multicolumn{6}{|l|}{ Treatment } \\
\hline Chemotherapyb & 225 & 56.3 & 152 & 53.9 & \\
\hline Radiotherapy $^{c}$ & 112 & 28.0 & 70 & 24.8 & \\
\hline Surgery only & 63 & 15.8 & 60 & 21.3 & 0.166 \\
\hline \multicolumn{6}{|l|}{ Bone marrow transplant } \\
\hline No & 392 & 95.6 & 269 & 94.1 & \\
\hline Yes & 18 & 4.4 & 17 & 5.9 & 0.356 \\
\hline \multicolumn{6}{|l|}{ Relapse } \\
\hline No & 406 & 99.0 & 281 & 98.3 & \\
\hline Yes & 4 & 1.0 & 5 & 1.7 & 0.375 \\
\hline
\end{tabular}

${ }^{\mathrm{a}}$ Age at study for non-participants refers to the last date they were contacted, ${ }^{\mathrm{b}}$ With or without surgery, ${ }^{\mathrm{c}}$ With or without chemotherapy or surgery 
TABLE II. Health Beliefs in Follow-Up Care Attendees and Non-Attendees

\begin{tabular}{|c|c|c|c|c|c|c|}
\hline & \multirow{2}{*}{$\begin{array}{c}\text { Total } \\
n\end{array}$} & \multicolumn{2}{|c|}{ Do not attend FU } & \multicolumn{2}{|c|}{ Attend FU } & \multirow{2}{*}{$p\left(\chi^{2}\right)$} \\
\hline & & $n$ & $\%$ & $n$ & $\%$ & \\
\hline \multicolumn{7}{|c|}{ Susceptibility: probability for late effects } \\
\hline $0 \%$ & 32 & 15 & 9.2 & 17 & 8.1 & \\
\hline $1-33 \%$ & 268 & 119 & 73.0 & 149 & 71.0 & \\
\hline $34-66 \%$ & 47 & 19 & 11.7 & 28 & 13.3 & \\
\hline $67-100 \%$ & 26 & 10 & 6.1 & 16 & 7.6 & 0.878 \\
\hline Missing & 37 & 18 & & 19 & & \\
\hline \multicolumn{7}{|c|}{ Severity: late effects will impair life } \\
\hline Not at all & 49 & 21 & 13.2 & 28 & 13.5 & \\
\hline Slightly & 152 & 62 & 39.0 & 90 & 43.5 & \\
\hline Moderately & 101 & 49 & 30.8 & 52 & 25.1 & \\
\hline A lot & 64 & 27 & 17.0 & 37 & 17.9 & 0.673 \\
\hline Missing & 44 & 22 & & 22 & & \\
\hline \multicolumn{7}{|c|}{ Benefits: follow-up detects and prevents late effects } \\
\hline Strongly disagree & 13 & 7 & 4.3 & 6 & 2.7 & \\
\hline Mostly disagree & 18 & 10 & 6.1 & 8 & 3.6 & \\
\hline Mostly agree & 115 & 61 & 37.4 & 54 & 24.5 & \\
\hline Strongly agree & 237 & 85 & 52.1 & 152 & 69.1 & 0.010 \\
\hline Missing & 27 & 18 & & 9 & & \\
\hline \multicolumn{7}{|c|}{ Barriers I: follow-up is not necessary } \\
\hline Strongly disagree & 238 & 93 & 56.4 & 145 & 66.2 & \\
\hline Mostly disagree & 101 & 45 & 27.3 & 56 & 25.6 & \\
\hline Mostly agree & 27 & 14 & 8.5 & 13 & 5.9 & \\
\hline Strongly agree & 18 & 13 & 7.9 & 5 & 2.3 & 0.033 \\
\hline Missing & 26 & 16 & & 10 & & \\
\hline \multicolumn{7}{|c|}{ Barriers II: fear of detecting late effects } \\
\hline Strongly disagree & 180 & 79 & 48.2 & 101 & 46.1 & \\
\hline Mostly disagree & 105 & 48 & 29.3 & 57 & 26.0 & \\
\hline Mostly agree & 66 & 25 & 15.2 & 41 & 18.7 & \\
\hline Strongly agree & 32 & 12 & 7.3 & 20 & 9.1 & 0.689 \\
\hline Missing & 27 & 17 & & 10 & & \\
\hline \multicolumn{7}{|c|}{ Cues to action: self-reported late effects } \\
\hline No & 266 & 133 & 76.0 & 133 & 59.6 & \\
\hline Yes & 132 & 42 & 24.0 & 90 & 40.4 & 0.001 \\
\hline Missing & 12 & 6 & & 6 & & \\
\hline \multicolumn{7}{|c|}{ Cues to action: how severe are current late effects ${ }^{\mathrm{a}}$} \\
\hline Not at all & 54 & 28 & 42.4 & 26 & 24.1 & \\
\hline Slightly & 70 & 20 & 30.3 & 50 & 46.3 & \\
\hline Moderately & 35 & 16 & 24.2 & 19 & 17.6 & \\
\hline A lot & 15 & 2 & 3.0 & 13 & 12.0 & 0.008 \\
\hline Missing & 2 & 0 & & 2 & & \\
\hline \multicolumn{7}{|c|}{ Cues to action: current health } \\
\hline Poor & 0 & 0 & 0.0 & 0 & 0.0 & \\
\hline Fair & 15 & 5 & 2.8 & 10 & 4.4 & \\
\hline Good & 85 & 38 & 21.0 & 47 & 20.7 & \\
\hline Very good & 180 & 86 & 47.5 & 94 & 41.4 & \\
\hline Excellent & 128 & 52 & 28.7 & 76 & 33.5 & 0.509 \\
\hline Missing & 2 & 0 & & 2 & & \\
\hline
\end{tabular}

${ }^{a}$ Only survivors who reported current late effects; FU: follow-up care 
Published in final edited form as: Pediatr Blood Cancer. 2016 Feb;63(2):318-25. doi: 10.1002/pbc.25755

\section{TABLE III. Predictors of Follow-Up Care Attendance}

\begin{tabular}{|c|c|c|c|c|c|c|c|c|c|}
\hline & \multirow{2}{*}{\multicolumn{3}{|c|}{ Univariable logistic regressions }} & \multicolumn{6}{|c|}{ Multivariable logistic regressions } \\
\hline & & & & \multicolumn{3}{|c|}{$\begin{array}{l}\text { Model 1: Demographic and } \\
\text { medical factors }\end{array}$} & \multicolumn{3}{|c|}{$\begin{array}{c}\text { Model 2: Health-beliefs, } \\
\text { demographic, and medical factors }\end{array}$} \\
\hline & OR & $95 \% \mathrm{CI}$ & $p^{\mathbf{a}}$ & OR & $95 \% \mathrm{CI}$ & $p^{\mathrm{a}}$ & $\mathbf{O R}$ & $95 \% \mathrm{CI}$ & $p^{\mathrm{a}}$ \\
\hline \multicolumn{10}{|l|}{ Health-beliefs $^{\mathrm{b}}$} \\
\hline Susceptibility & 1.00 & 0.99-1.01 & 0.678 & & & & 1.01 & $0.99-1.02$ & 0.448 \\
\hline Severity & 0.93 & $0.73-1.17$ & 0.526 & & & & 0.86 & $0.65-1.13$ & 0.147 \\
\hline Benefits & 1.59 & $1.18-2.16$ & 0.002 & & & & 1.56 & $1.07-2.27$ & 0.017 \\
\hline Barriers I & 0.67 & $0.51-0.89$ & 0.004 & & & & 0.70 & $0.50-1.00$ & 0.041 \\
\hline Barriers II & 0.99 & $0.80-1.23$ & 0.914 & & & & 0.98 & $0.75-1.28$ & 0.677 \\
\hline Late effects & 1.08 & $0.90-1.31$ & 0.398 & & & & 1.08 & $0.87-1.35$ & 0.268 \\
\hline Health status & 0.94 & $0.72-1.22$ & 0.645 & & & & 1.16 & $0.83-1.63$ & 0.560 \\
\hline \multicolumn{10}{|l|}{ Demographic characteristics } \\
\hline Female & 0.95 & $0.62-1.46$ & 0.806 & 1.03 & $0.64-1.66$ & 0.889 & 0.99 & $0.60-1.66$ & 0.780 \\
\hline Born abroad & 1.43 & $0.66-3.08$ & 0.357 & 0.67 & $0.28-1.60$ & 0.527 & 0.67 & $0.27-1.65$ & 0.512 \\
\hline \multicolumn{10}{|l|}{ Language (vs. German) } \\
\hline French & 1.00 & $0.62-1.62$ & & 0.83 & $0.48-1.43$ & & 0.71 & $0.40-1.28$ & \\
\hline Italian & 0.91 & $0.27-3.07$ & 0.989 & 0.55 & $0.13-2.25$ & 0.600 & 0.38 & $0.09-1.61$ & 0.266 \\
\hline Age at study & 0.90 & $0.75-1.08$ & 0.243 & 0.95 & $0.77-1.18$ & 0.074 & 0.94 & $0.76-1.18$ & 0.161 \\
\hline \multirow{2}{*}{\multicolumn{10}{|c|}{$\begin{array}{l}\text { Medical characteristics } \\
\text { Time since diagnosis (vs. 5-9 } \\
\text { years) }\end{array}$}} \\
\hline & & & & & & & & & \\
\hline 10-14 years & 0.28 & $0.14-0.58$ & & 0.24 & $0.11-0.52$ & & 0.21 & $0.10-0.47$ & \\
\hline $15+$ years & 0.13 & $0.06-0.26$ & $<0.001$ & 0.11 & $0.05-0.24$ & $<0.001$ & 0.10 & $0.05-0.23$ & $<0.001$ \\
\hline \multicolumn{10}{|l|}{ Cancer diagnosis (vs. leukemia) } \\
\hline Lymphoma & 1.38 & $0.68-2.80$ & & 0.84 & $0.37-1.91$ & & 0.75 & $0.32-1.72$ & \\
\hline CNS tumor & 1.89 & $0.94-3.78$ & & 1.47 & $0.61-3.56$ & & 1.60 & $0.63-4.05$ & \\
\hline Bone tumor & 1.85 & $0.80-4.25$ & & 2.37 & $0.91-6.15$ & & 2.56 & $0.92-7.13$ & \\
\hline Other tumor & 0.73 & $0.42-1.25$ & 0.035 & 0.99 & $0.54-1.83$ & 0.316 & 0.98 & $0.52-1.85$ & 0.231 \\
\hline \multicolumn{10}{|l|}{ Therapy (vs. chemotherapy ${ }^{\mathrm{c}}$ ) } \\
\hline Radiotherapy ${ }^{\mathrm{d}}$ & 1.74 & $1.05-2.90$ & & 1.42 & $0.78-2.59$ & & 1.63 & $0.87-3.06$ & \\
\hline Surgery only & 1.00 & $0.53-1.87$ & 0.083 & 0.74 & $0.32-1.67$ & $<0.001$ & 0.89 & $0.37-2.11$ & $<0.001$ \\
\hline Had bone marrow transplantation & 12.30 & $1.61-94.25$ & $<0.001$ & 15.21 & $1.87-123.53$ & 0.002 & 19.15 & $2.25-163.07$ & 0.001 \\
\hline $\begin{array}{l}N \\
\text { Overall } p\end{array}$ & & & 340 & & & $\begin{array}{r}340 \\
<0.001\end{array}$ & & & $\begin{array}{r}340 \\
<0.001\end{array}$ \\
\hline
\end{tabular}

a $p$ refers to likelihood ratio testing, b Susceptibility: for having late effects in the next 10 years; Severity: "If I suffer from late effects, this will considerably impair my life;" Benefits: "Regular follow-up may help in detecting late effects and preventing negative consequences of late effects;” Barriers: (I) "Regular follow-up is not necessary” and

(II) "At regular follow-up appointments, I fear that negative late effects of my cancer will be found.”, ${ }^{\mathrm{c}}$ With or without surgery, ${ }^{\mathrm{d}}$ With or without chemotherapy or surgery,

$\mathrm{CI}$ : confidence interval; OR: odds ratio, $\mathrm{N}$ : number of subjects in analyses 
Published in final edited form as: Pediatr Blood Cancer. 2016 Feb;63(2):318-25. doi: 10.1002/pbc.25755

Figure 1. Participants in Analysis

Eligible survivors: Eligible for the SCCSS adolescent questionnaire (aged 16-19 at time of first contact )

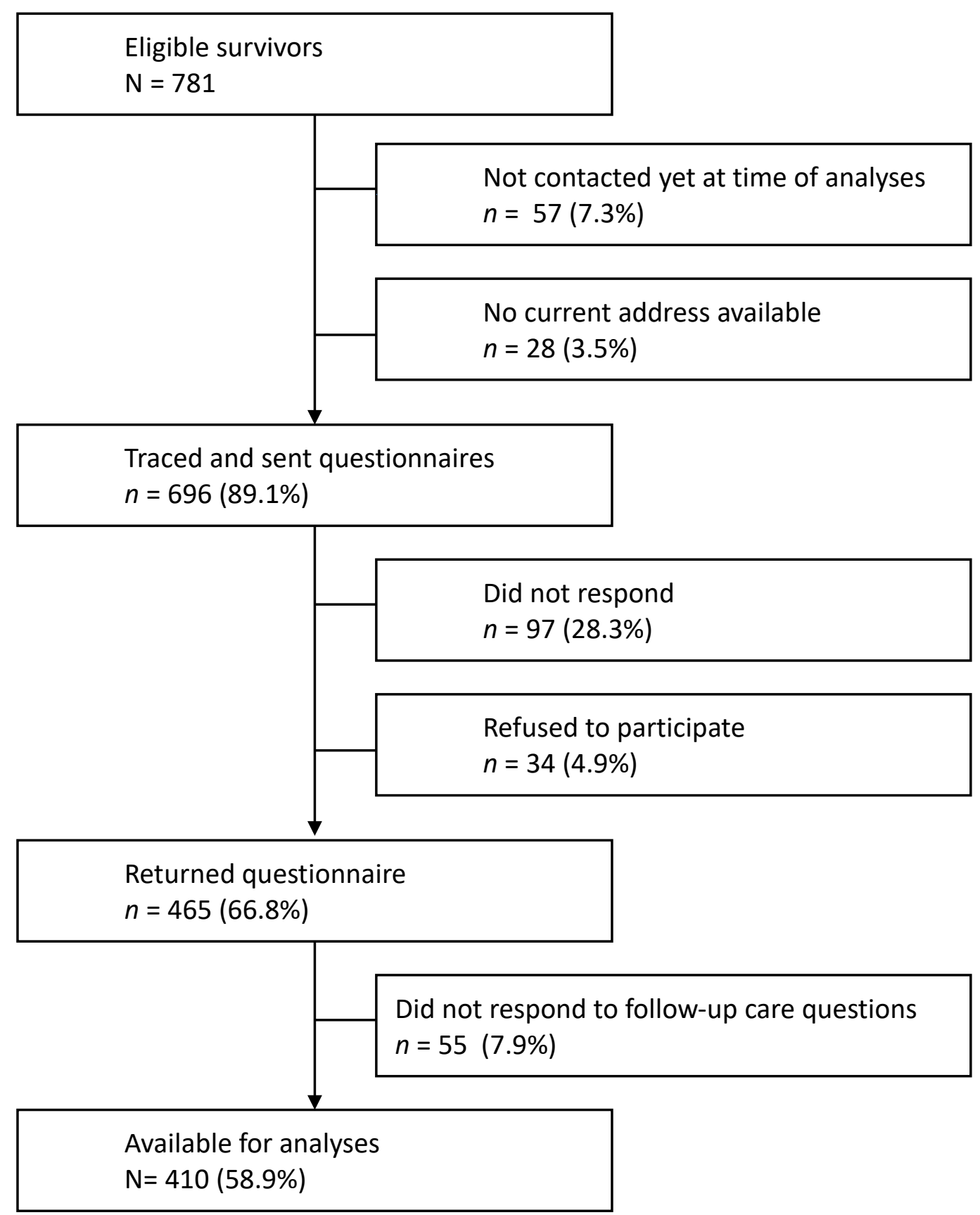


Published in final edited form as: Pediatr Blood Cancer. 2016 Feb;63(2):318-25. doi: 10.1002/pbc.25755

\section{Supplemental Material}

In this file we present the information letter sent to the survivors before the study and the letter we sent together with the questionnaire (each letter was available in German, French and Italian). Each letter was signed by the head of the pediatric oncology clinic where the survivor was treated for their cancer and by the head of the Swiss Childhood Cancer Registry and the Swiss Childhood Cancer Survivor Study.

\section{Supplemental Text 1: Information letter from paediatric oncology clinic}

\section{German}

\section{Jugendalter}

Vorankündigung: Gesundheitsbefragung nach Erkrankung im Kindes- und

$\rightarrow$ Si vous ne parlez pas l'allemand veuillez lire les informations sur la feuille jointe.

Lieber Vorname Nachname

Sie waren in unserer Kinderklinik in Behandlung wegen einer Leukämie, Tumorerkrankung (auch gutartig) oder einer anderen seltenen Erkrankung. Um die bestmögliche Betreuung dieser seltenen Krankheiten zu garantieren, ist der Wissensaustausch zwischen Ärzten extrem wichtig. Daher wird seit 1976 die Behandlung dieser Erkrankungen im Schweizer Kinderkrebsregister ausgewertet (www.kinderkrebsregister.ch).

Dank dieser Zusammenarbeit von Ärzten und Wissenschaftlern wurden enorme Fortschritte gemacht, so dass heute die meisten krebskranken Kinder geheilt werden. Wir wissen aber, dass bei gewissen Patienten Jahre nach erfolgreicher Behandlung Gesundheitsprobleme auftreten können. Eine Früherkennung dieser Spätfolgen ermöglicht es oft, Komplikationen zu vermeiden oder zu mildern.

Aus diesem Grund kontaktieren wir alle betroffenen Personen in der Schweiz und werden auch Ihnen innerhalb der nächsten zwei Wochen einen Fragebogen schicken. Bisher haben wir schon über 2500 Fragebogen zurückbekommen.

Falls Sie den Fragebogen in einer anderen Sprache wünschen oder uns eine Adressberichtigung mitteilen möchten, bitten wir Sie um eine kurze Rückmeldung. Die Kontaktpersonen für die Studie sind: NAME, Schweizer Kinderkrebsregister, Institut für Sozialund Präventivmedizin, Finkenhubelweg 11, 3012 Bern; E-Mail: , Tel:.

Wenn wir nichts von Ihnen hören, werden wir Ihnen den Fragebogen innerhalb der nächsten zwei Wochen zuschicken. Ganz herzlichen Dank schon jetzt, denn Ihre Mitarbeit wird uns helfen, die Behandlung von krebskranken Kindern weiter zu verbessern.

Mit freundlichen Grüssen

Abteilungsleiter Päd. Hämato-/Onkologie

Leiterin Schweizer Kinderkrebsregister 


\section{French:}

\section{Annonce: Questionnaire de santé après une maladie durant l'enfance ou l'adolescence}

$\rightarrow$ Falls Sie kein Französisch sprechen, lesen Sie bitte die Informationen auf dem beigelegten Blatt.

Cher „Vorname“ „Nachname“

Chère „Vorname“ „Nachname“

Vous avez été traité(e) dans notre Unité d’Oncologie pédiatrique pour une leucémie, une tumeur (bénigne ou maligne) ou une autre maladie rare. Afin de garantir le meilleur traitement possible pour ces maladies rares, l'échange d'informations entre les médecins est extrêmement important. C'est pour cette raison que, depuis 1976, le suivi de ces maladies est analysé par le Registre Suisse du Cancer de l’Enfant (www.registretumeursenfants.ch).

Cette collaboration entre médecins et chercheurs a permis d'immenses progrès: aujourd'hui, la majorité des enfants atteints de cancer peut être guérie. Nous savons cependant que des problèmes de santé peuvent survenir chez certains patients des années après le traitement. Grâce à un dépistage soigneux de ces effets tardifs, il est souvent possible d'éviter des conséquences graves ou au moins de les traiter à temps et ainsi les atténuer.

C'est pour cette raison que nous vous contactons, ainsi que toutes les personnes concernées en Suisse, et vous enverrons un questionnaire. Jusqu'à présent, plus de 2500 questionnaires nous ont déjà été retournés.

Si vous préférez le questionnaire dans une autre langue ou souhaitez nous indiquer une correction d'adresse, nous vous prions de nous contacter. Les personnes à contacter pour l'étude sont: NAME, Registre Suisse du Cancer de l'Enfant, Institut de Médecine Sociale et Préventive, Finkenhubelweg 11, 3012 Berne; e-mail: , tél: .

Si nous n'entendons rien de votre part, nous vous enverrons le questionnaire dans les prochains jours. Nous vous remercions déjà de votre collaboration, qui nous aidera à améliorer continuellement le suivi des enfants atteints d'un cancer.

Avec nos meilleures salutations

Médecin-chef Hématologie / Oncologie pédiatrique

Directrice du Registre Suisse du Cancer de l’Enfant 


\section{Italian:}

\section{Questionario dopo malattia in età pediatrica}

Spettabile Signor/Signora

Come già annunciato, troverà in allegato il questionario sulla sua salute. È diretto ad adolescenti e giovani adulti, i quali durante l'infanzia si sono ammalati di una leucemia, di un tumore solido (anche benigno) o di un'altra malattia rara. I risultati di questa inchiesta ci aiuteranno a ottimizzare il trattamento dei bambini malati di cancro, come pure a migliorare il depistaggio precoce dei possibili effetti a lungo termine dovuti al trattamento.

L'inchiesta è condotta dal Gruppo Svizzero di Oncologia Pediatrica (SPOG) e dall'istituto di medicina preventiva e sociale dell'Università di Berna, e sostenuta da associazioni di pazienti e genitori (Kinderkrebshilfe Schweiz, Swiss Childhood Cancer Survivors, Lega contro il Cancro). Troverà ulteriori informazioni sullo studio e sul registro del cancro dei bambini sul sito www.kinderkrebsregister.ch.

I risultati di quest'analisi aiuteranno a migliorare ulteriormente la cura dei tumori nei bambini e la loro presa a carico dopo la terapia. Ci rendiamo conto che per alcuni di voi non risulterà facile compilare il questionario; potrebbero riaffiorare alcuni ricordi dolorosi. Ragion per cui le siamo ancora più riconoscenti se potesse darci il suo importante contributo e feedback. Solo se riceviamo il maggior numero di risposte, i nostri risultati saranno significativi. Naturalmente i suoi dati saranno gestiti in maniera confidenziale e anonima.

Se non riuscisse a compilare il questionario da solo, le saremmo grati se persone vicine a lei la possano aiutare. Per eventuali difficoltà o domande non esiti a contattare NAME: tel., e-mail:).

Può rispedirci il suo questionario gratuitamente con la busta già affrancata in allegato.

La ringraziamo sin d'ora e le porgiamo i nostri più cordiali saluti. 
Published in final edited form as: Pediatr Blood Cancer. 2016 Feb;63(2):318-25. doi: 10.1002/pbc.25755

\section{Supplemental Text2: Cover letter sent with the questionnaire}

\section{German:}

\section{Gesundheitsbefragung nach Erkrankung im Kindes- und Jugendalter}

Lieber Vorname Nachname

Wie angekündigt senden wir Ihnen den Fragebogen zu Ihrer Gesundheit. Er richtet sich an Kinder, Jugendliche und junge Erwachsene, welche im Kindes- oder Jugendalter eine Leukämie, Tumorerkrankung (auch gutartig) oder eine andere seltene Erkrankung hatten.

Die Untersuchung wird von der Schweizerischen Pädiatrischen Onkologiegruppe (SPOG) und dem Institut für Sozial- und Präventivmedizin der Universität Bern durchgeführt, unterstützt von Patienten- und Elternvereinigungen (Kinderkrebshilfe Schweiz, Swiss Childhood Cancer Survivors, Krebsliga). Weitere Informationen über die Studie und das Kinderkrebsregister finden Sie unter: www.kinderkrebsregister.ch.

Die Ergebnisse dieser Untersuchung werden helfen, die Krebsbehandlung bei Kindern weiter zu optimieren, sowie die Nachsorge zu verbessern.

Es ist uns bewusst, dass einigen von Ihnen das Ausfüllen des Fragebogens nicht leicht fällt; vielleicht werden schmerzliche Erinnerungen geweckt. Umso dankbarer sind wir, wenn Sie uns trotzdem dieses wichtige Feedback geben. Nur wenn wir möglichst viele Antworten erhalten sind die Ergebnisse der Untersuchung aussagekräftig.

Falls Sie den Fragebogen nicht selber ausfüllen können, sind wir dankbar, wenn Verwandte oder Freunde dabei helfen. Bei Schwierigkeiten oder Fragen beim Ausfüllen dürfen Sie sich gerne an NAME wenden (Tel:; E-Mail:).

Selbstverständlich werden wir Ihre Angaben streng vertraulich behandeln und nur anonym auswerten.

Sie können den Bogen gratis im beigelegten vorfrankierten Couvert zurücksenden.

Mit freundlichen Grüssen und ganz herzlichem Dank im Voraus

Abteilungsleiter Päd. Hämato-/Onkologie ～Leiterin Schweizer Kinderkrebsregister 


\title{
French:
}

\section{Questionnaire de santé après une maladie grave durant l'enfance ou l'adolescence}

\author{
Cher / Chère NAME
}

Comme annoncé dans un courrier précédent, nous vous envoyons le questionnaire sur votre état de santé: il s'adresse aux adolescents et aux jeunes adultes qui ont été atteints d'une leucémie, d'une maladie tumorale (bénigne ou maligne) ou d'une autre maladie rare.

Cette recherche est menée par le Groupe d'Oncologie Pédiatrique Suisse (SPOG) et par l'Institut de Médecine Sociale et Préventive de l'Université de Berne. Nous avons le soutien de plusieurs organisations de patients et de parents (Kinderkrebshilfe Schweiz, Swiss Childhood Cancer Survivors, Ligue Suisse Contre le Cancer). Vous trouverez plus d'informations sur l'étude et le Registre Suisse du Cancer de l'Enfant sur: www.registretumeursenfants.ch.

Les résultats de cette enquête contribueront à l'amélioration du traitement et le suivi du cancer des enfants.

Nous savons que, pour certains d'entre vous, il ne sera pas forcément facile de remplir ce questionnaire; peut-être que de souvenirs douloureux seront réveillés. Nous vous sommes d'autant plus reconnaissants de votre participation, qui est si importante. Seules des réponses d'une grande majorité des personnes concernées peuvent garantir la validité des résultats de cette recherche.

Si vous ne pouvez pas remplir le questionnaire vous-même, demandez de l'aide à des membres de votre famille ou à des amis. En cas de difficulté ou si vous avez des questions au moment du remplissage, vous pouvez vous adresser à NAME (tél:; e-mail:)

Vos données seront bien sûr traitées de manière strictement confidentielle et analysées anonymement.

Vous pouvez nous retourner votre questionnaire gratuitement dans l'enveloppe-réponse cijointe.

Avec nos meilleures salutations et nos remerciements anticipés

Médecin-chef Hématologie / Oncologie pédiatrique Directrice du Registre Suisse du Cancer de l'Enfant 


\section{Italian:}

\section{Questionario dopo malattia in età pediatrica}

Spettabile Signor/Signora

Come già annunciato, troverà in allegato il questionario sulla sua salute. È diretto ad adolescenti e giovani adulti, i quali durante l'infanzia si sono ammalati di una leucemia, di un tumore solido (anche benigno) o di un'altra malattia rara. I risultati di questa inchiesta ci aiuteranno a ottimizzare il trattamento dei bambini malati di cancro, come pure a migliorare il depistaggio precoce dei possibili effetti a lungo termine dovuti al trattamento.

L'inchiesta è condotta dal Gruppo Svizzero di Oncologia Pediatrica (SPOG) e dall'istituto di medicina preventiva e sociale dell'Università di Berna, e sostenuta da associazioni di pazienti e genitori (Kinderkrebshilfe Schweiz, Swiss Childhood Cancer Survivors, Lega contro il Cancro). Troverà ulteriori informazioni sullo studio e sul registro del cancro dei bambini sul sito www.kinderkrebsregister.ch.

I risultati di quest'analisi aiuteranno a migliorare ulteriormente la cura dei tumori nei bambini e la loro presa a carico dopo la terapia. Ci rendiamo conto che per alcuni di voi non risulterà facile compilare il questionario; potrebbero riaffiorare alcuni ricordi dolorosi. Ragion per cui le siamo ancora più riconoscenti se potesse darci il suo importante contributo e feedback. Solo se riceviamo il maggior numero di risposte, i nostri risultati saranno significativi. Naturalmente i suoi dati saranno gestiti in maniera confidenziale e anonima.

Se non riuscisse a compilare il questionario da solo, le saremmo grati se persone vicine a lei la possano aiutare. Per eventuali difficoltà o domande non esiti a contattare la NAME: tel., e-mail: ).

Può rispedirci il suo questionario gratuitamente con la busta già affrancata in allegato. Pediatrici

Spec. FMH pediatria e oncologia pediatrica Direttrice Registro Svizzero Tumori 